\section{State and Local}

\section{Capturing the Moment: Local Government Publications}

\section{Shari Laster and Aimée C. Quinn}

W hen it comes to identifying and accessing government information sources, publications from local government offices and departments can be one of the toughest areas out there. Local or municipal governments are typically categorized based on the category of government subdivision they fit, such as counties, cities, towns, or districts, but they are more frequently requested and accessed based on the surrounding geography. Some functions can be carried out in partnership with other government entities, as when a water or parks district works in concert with a county government; or when agencies at the regional level work directly under the mandate of a state or provincial government.

For a historic overview of issues and practices related to local government information covering 1987-2000, the series of bibliographies compiled by Kathy A. Parsons, Margaret T. Lane, Gayle C. Christensen, and others on behalf of GODORT's State and Local Documents Task Force is an interesting source to peruse. ${ }^{1}$ In the titles of these articles and reports, one finds similar opportunities and issues faced today in identifying, collecting, describing, and managing these materials. While the internet has drastically improved immediate accessibility to government publications, it has also endangered older publications, which may be one site update away from inaccessibility.

The number of local governments that make content available online continues to grow, and the types of information and services offered expands. In particular, public access to government information is the primary reason local governments venture into e-government, and remains a crucial reason for expanding their electronic offerings, along with saving money. ${ }^{2}$ Some jurisdictions continue to make resources available in print to serve the needs of local users, or to meet specific legal obligations, while others have transitioned to electronic distribution in order to save the costs associated with printing and distributing materials.

Although making publications available on a website can increase their discoverability, navigating government websites is not always intuitive, particularly when content is posted with minimal metadata. Issues of the digital divide and e-government have also received attention in recent years. ${ }^{3}$ As research has noted, there can be substantial differences in the amount of content local governments make available online. Factors including professional management, socioeconomic characteristics, and local population can affect the availability of e-government resources and services. ${ }^{4}$ A recent study exploring online public records from Florida counties and school boards also found that differing levels of professionalism in web design affected the amount of content available on these government websites. ${ }^{5}$

Because local government publications are less widely disseminated, an active collection program is important for ensuring the future availability of these resources. In particular, documents published solely to the web are at risk for succumbing to link rot, whether through the process of routine maintenance activities, or as a result of web design changes, administrative reorganization, or human error. In particular, when documents are composed of multiple parts, as with an HTML page that organizes multiple PDF documents, active collection and curation improves the likelihood that the content will be discoverable and usable in the future.

While finding time to undertake a local government publication project is no doubt a challenge, the time spent can be justified by the creation of an entirely unique collection for the library that can, with proper steps taken to describe the content and make it available, perhaps become a showcase collection. It is also an opportunity to improve connections between a library and the surrounding community, which can help with referrals and outreach.

For a new project, it's wise to start small—in this case, with the geographically closest jurisdictions. It's also a good idea to identify other libraries and archives that may have complementary collections to identify gaps or determine which materials are of particular interest in the local community. Also, determine what local resources are available for creating a unique collection within the library: is there interest in building a collection in print or in collecting digital documents for future availability? Can the metadata be created as part of existing workflows or as a special project? If the capacity is not available to create full bibliographic records, how else can the materials be organized and made accessible?

Once a list of jurisdictions of interest has been identified, review the websites of these jurisdictions to identify materials potentially of interest for the collection. Documents and publications in print format can often be requested directly from agency offices. If an office is required to make a certain number of copies available for public inspection, one or more of these copies may be "free to a good home" after the public review period. In some cases, offices may have extra copies sitting around, and administrative staff may be happy or even relieved to learn that a library is interested in taking care of these materials for the long term. 
Digital publications available in PDF or HTML format can be saved to a local server or institutional repository, or printed and bound for local users. Local government websites are also excellent candidates for web harvesting. For example, an academic library hosting its university's archives may already have procedures in place for capturing web content from the university's administration. Databases and other complex resources may take more creativity and collaboration to collect, but working with government agencies to ensure long-term access to their content can be framed as an opportunity for the library to serve its local community.

One final point to ensure permanent access to local collections is to document the reasons and agreements for the collections. Make certain library administrations are informed and agree to the rationales prior to initiating agreements with outside organizations. Ensuring these steps from the outset will ensure the future of these projects in the long-run especially as staffing and technological changes take place.

Shari Laster (slaster@ucsb.edu) is Government Data \& Information Librarian, University of California, Santa Barbara. Aimée C. Quinn (aimee.quinn@cwu.edu) is Government Publications Librarian, Central Washington University.

\section{References}

1. These bibliographies are available on the GODORT wiki: http://wikis.ala.org/godort/index.php/State_and_Local _Documents_Bibliographies.

2. Donald F. Norris and Christopher G. Reddick 2013. "Local e-government in the United States: Transformation or incremental change?” Public Administration Review 73: 165-75, http://dx.doi.org/10.1111/j.1540-6210.2012.02647.x.

3. Katharine Macy, "Digital Divide Challenges: Access to E-government," DttP 42, no. 4 (2014): 36-40.

4. Tony E. Wohlers, "The Digital World of Local Government: A Comparative Analysis of the United States and Germany," Journal of Information Technology \& Politics 6, no. 2 (2009): 111-26, http://dx.doi .org/10.1080/19331680902821593.

5. Cory L. Armstrong, "Providing a Clearer View: An Examination of Transparency on Local Government Websites," Government Information Quarterly 28, no. 1 (2011): 11-16, http://dx.doi.org/10.1016/j.giq.2010.07.006. 